\title{
Production and in vitro viability of pollen of peach trees grown in subtropical climate
}

\author{
Claudia Regina Barbieri ${ }^{1}$ \& Gilmar Antônio Nava ${ }^{2}$
}

\begin{abstract}
Studies of the production and viability of pollen are very important in breeding programs and for assessing the climatic adaptation of fruit species. The objective of this work was to determine the pollen production per anther and its viability from in vitro germination tests of 16 peach cultivars. The analyses were carried out at the Horticulture Laboratory with vegetable matter from the peach trees in the fruit sector of the Federal Technological University of Paraná, Dois Vizinhos, Paraná State, Brazil. The cultivars used in the research were: Bonão, BR-1, Charme, Chimarrita, Coral, Douradão, Eldorado, Fascínio, Granada, Kampai, Leonense, Marli, Regalo, Riograndense, Rubimel, and Zilli. Pollen production was obtained by counting in a Neubauer chamber. In vitro germination of pollen was obtained after incubation of pollen in culture through a controlled environment (presence of photoperiod and temperature of $25^{\circ} \mathrm{C}$ ). The experimental design used was completely randomized with four replications. The data were submitted to the Lilliefors normality test and to variance analysis and means comparisons by the Scott-Knott test $(\alpha=0.05)$. We concluded that the winter conditions of 2016 were better for the development of the buds, which promoted greater production of pollen per anther. The cultivars Douradão, Leonense, Regalo, and Rubimel had the highest rates of pollen viability. The storage of pollen at $-20^{\circ} \mathrm{C}$ for 60 days reduced its average viability by $42 \%$. Four hours of incubation with photoperiod, is enough to promote the germination of peach pollen. Index terms: Prunus persica L. Batsch, Cultivars, Production and pollen germination, Climatic adaptation.
\end{abstract}

\section{Produção e viabilidade in vitro de pólen de pessegueiros}

Corresponding author: crbbio@hotmail.com

Received: August 23, 2019 Accepted: April 16, 2020

Copyright: All the contents of this journal, except where otherwise noted, is licensed under a Creative Commons Attribution License.

\section{(cc) $\mathbf{E Y}$}

\section{cultivados em clima subtropical}

Resumo-Estudos sobre a produção e a viabilidade do pólen são de suma importância em programas de melhoramento genético e para a avaliação da adaptação climática das espécies frutíferas. Assim, o objetivo deste trabalho foi determinar a taxa de produção de pólen por antera e sua viabilidade em testes de germinação in vitro, de 16 cultivares de pessegueiros. As análises foram realizadas no Laboratório de Horticultura com material vegetal oriundo da coleção de pessegueiros do setor de Fruticultura, da Universidade Tecnológica Federal do Paraná, Câmpus Dois Vizinhos-PR. As cultivares utilizadas na pesquisa foram: Bonão, BR-1, Charme, Chimarrita, Coral, Douradão, Eldorado, Fascínio, Granada, Kampai, Leonense, Marli, Regalo, Riograndense, Rubimel e Zilli. A produção de pólen foi obtida através da contagem em câmara de Neubauer. A germinação in vitro do pólen foi obtida após incubação do pólen em meio de cultura sob ambiente controlado (fotoperíodo e temperatura de $25^{\circ} \mathrm{C}$ ). O delineamento experimental utilizado foi inteiramente casualizado, com quatro repetições. Os dados foram submetidos ao teste de normalidade de Lillefors, à análise de variância (ANOVA) e às comparações de médias, pelo teste de Scott-Knott, a 5\%. Conclui-se que as condições de inverno de 2016 foram melhores para o desenvolvimento das gemas, o qual promoveu maior produção de pólen por antera. As cultivares Douradão, Leonense, Regalo e Rubimel obtiveram os maiores índices de viabilidade de pólen. A armazenagem do pólen a $-20{ }^{\circ} \mathrm{C}$, por 60 dias, reduziu sua viabilidade média em $42 \%$. Quatro horas de incubação, com fotoperíodo, é tempo suficiente para promover a germinação do pólen do pessegueiro.

Termos para Indexação: Prunus persica L. Batsch, Variedades, Germinação do pólen, Adaptação climática.

${ }^{1}$ Biologist, M.Sc. in Agroecosystems, PhD student in Agronomy at the Federal Technological University of Paraná, Pato Branco, Paraná State, Brazil. E-mail: crbbio@hotmail.com (ORCID 0000-0001-6922-5521)

${ }^{2}$ Agronomist, Dr. in Phytotechnics, Professor at the Federal Technological University of Paraná, Dois Vizinhos, Paraná State, Brazil, Brazil. E-mail: gilmarnava@utfpr.edu.br ${ }^{\text {(ORCID 0000-0002-6133-9476) }}$ 


\section{Introduction}

The Brazil produced about 219,000 tons of peaches in 2018, in an area of 18,000 hectares, and the State of Rio Grande do Sul was the biggest national producer. In that year, Paraná also allocated 932 hectares for the cultivation of peach trees, producing about 12,000 tons of peaches (IBGE, 2020).

A large part of the state of Paraná has wavy topography, causing transient climatic diversity from the tropical to the temperate climate. Some regions therefore do not experience the number of cold hours $(\mathrm{CH})$ required to overcome the dormancy of the buds of the species and cultivars, and so are considered risk zones for agricultural production (CARAMORI et al., 2008). Thus, the adaptation of peach cultivars in the conditions of milder winters prevents the sprouting and flowering from being insufficient and sporadic, damaging the fruit production (WAGNER JÚNIOR et al., 2010).

The peach tree grows and fruits well in regions of Köppen's Cfa climate (mesothermal, hot and rainy summer) common in the South and part of Southeast of Brazil, but is considerate the Cfb climate (humid mesothermal, with fresh and mild summers), more suitable for the species than the Cfa climate (GOMES, 2007). Peaches are therefore more widely cultivated at $22-33^{\circ} \mathrm{S}$ of the Equator (PETRI et al., 2002).

Research on the evaluation and selection of cultivars has fundamental importance to understand phenological behavior and adaptations to the edaphoclimatic conditions of the region, and assist in the planting of commercial orchards of productive peach trees because the flowering, sprouting, and fruiting directly depend on environmental conditions, primarily temperature (CHAGAS et al., 2009; ALMEIDA et al., 2014).

According to Barbosa et al. (1989), peach trees with good edaphoclimatic adaptation can produce from 1,000 to 2,000 pollen grains per anther and up to 80,000 pollen grains per flower. However, several factors can influence the pollen production and viability, such as genes (cultivars), temperature in pre-flowering and flowering (NAVA et al., 2009), the development stage of flower at the time of pollen gathering, and the conditions of its storage, since the variation of humidity and ambient temperature can cause changes in the viability of pollen grains, in addition to differences between species (FRANZON; RASEIRA; WAGNER JÚNIOR, 2007).

For the assessment of pollen viability, several in vitro techniques can be used, among them the use of culture methods with agar and sucrose to provide osmotic balance and energy supply for the germination and development of pollen tubes (CHAGAS et al., 2009). The mean of culture, temperature, and time required for germination are also important factors for the success of pollen germination; and the formation and emission of the pollen tube are determining characteristics of its viability (EINHARDT; CORREA; RASEIRA, 2006).

Based on the findings or previous research presented above, the objective of this study was to determine the production and in vitro viability of pollen from 16 peach cultivars grown in a subtropical climate.

\section{Material and methods}

This work was conducted in the collection of peach trees of the fruit sector and in the Horticulture Laboratory at the Federal Technological University of Paraná, Campus Dois Vizinhos, Southwest of Paraná, Brazil, on $25^{\circ} 45^{\prime} 00^{\prime \prime} \mathrm{S}, 53^{\circ} 03^{\prime} 25^{\prime \prime} \mathrm{W}$. According to the Köppen classification, the local climate is humid subtropical: $\mathrm{Cfa}$, with temperatures $>22{ }^{\circ} \mathrm{C}$ in the hottest months and $<18$ ${ }^{\circ} \mathrm{C}$ in the coldest months, and an average rainfall of 2,025 mm per year (ALVAREZ et al., 2013).

The cultivars used in the research were: Bonão, BR-1, Charme, Chimarrita, Coral, Douradão, Eldorado, Granada, Leonense, Marli, Riograndense, Rubimel (planted in 2009), and Fascínio, Kampai, Regalo, Zilli (planted in 2014), on the Capdeboscq rootstock. The planting spacing was $4.0 \times 5.0 \mathrm{~m}$, and the vase plant conduction system used. The orchard was managed according to the precepts of integrated peach production.

At full bloom (about $70 \%$ of flowers opened) of each cultivar, 20 pink balloons were collected per experimental unit at random. In the laboratory, each balloon had its petals and anthers removed with tweezers, and the anthers were deposited in a petri dish for the evaluation of the following characteristics.

\section{Pollen production}

To estimate pollen production per anther, 50 anthers were randomly separated per experimental unit and placed inside a $10 \mathrm{~mL}$ glass vial and kept open at room temperature for seven days, so that the pollen grains were released uniformly. Subsequently, $1000 \mu \mathrm{L}$ of lactic acid was added to suspend the pollen grains, and the vial was sealed with a rubber cap and placed in a refrigerator for later counting of the number of pollen grains per anther in a mirrored Neubauer chamber.

With the aid of a pipette, $100 \mathrm{~mL}$ of the suspension containing the pollen was removed and applied under the coverslip of the Neubauer chamber, so that the entire suspension drained and covered all counting fields, over which it was read under optical microscope with 10 increases (10x). The number $(\mathrm{N})$ of pollen grains per anther was obtained by the equation used by Carvalho (1989), and Nava et al. (2009): 


$$
N=a * \frac{\operatorname{vol}_{A L}}{\operatorname{vol}_{C N}} * \frac{1}{n_{a}}
$$

$a$ : average number of pollen grains in the sample corresponding to the treatment (cultivar);

$\mathrm{vol}_{A L}$ : volume of lactic acid $\left(\mathrm{mm}^{3}\right)$;

vol ${ }_{C N}$ : volume of the Neubauer chamber $\left(\mathrm{mm}^{3}\right)$;

$n a$ : number of anthers in the suspension.

The experimental design was completely randomized with four replications, using duplicate slides for each cultivar repetition to obtain the average number of pollen grains per anther.

\section{In vitro viability of pollen}

To determine in vitro viability of pollen, pollen from the remaining anthers removed from the floral balloons was used. These anthers were kept in petri dishes at room temperature for seven days to release the pollen. The pollen from each experimental unit was then transferred to $10 \mathrm{~mL}$ glass vials closed with cotton and placed in a glass desiccator with silica, which was kept in a freezer for 60 days $\left(-20^{\circ} \mathrm{C}\right)$ after Carvalho (1989), and Nava (2007).

For the germination of pollen, a mean of culture was prepared with $1 \mathrm{~g}$ of agar, $10 \mathrm{~g}$ sucrose, and 100 $\mathrm{mL}$ distilled water, which was autoclaved for complete sterilization, and poured still hot into a petri dish to $3 \mathrm{~mm}$ thickness. After solidified, the mean of culture was cut into $2 \mathrm{~cm} \times 2 \mathrm{~cm}$ squares and two counting fields per blade were placed to make an experimental unit. The pollen was distributed evenly over the mean of culture on the blades with the help of a brush. After depositing the pollen, the blades were placed in Gerbox ${ }^{\circledR}$ boxes with moist paper towels, simulating a humid chamber, and taken to Biochemical Oxygen Demand (BOD) chamber, being the pollen incubated at $25 \pm 0.5^{\circ} \mathrm{C}$, with a photoperiod of 16 hours.

After the incubation time, the blades were observed under a binocular biological microscope at 10 $\mathrm{x}$ magnification, followed by the counting of 100 pollen grains between germinated and not germinated per counting field. Pollen grains that had a pollen tube with a size equal to or greater than its diameter were considered germinated.

In 2016, two incubation times were tested in the BOD (4 and 20 hours) after drying time (seven days at room temperature, plus 60 days in a desiccator with silica at $-20{ }^{\circ} \mathrm{C}$ ). The experimental design was completely randomized in a $16 \times 2$ factorial scheme (cultivars $\mathrm{x}$ pollen incubation times), with 4 replicates of one blade each. In 2017, the germination of dry pollen for 7 days at ambient temperature (freshly dried) was compared with dry pollen for 7 days at ambient temperature plus 60 days in the desiccator with silica at $-20{ }^{\circ} \mathrm{C}$, for four hours of incubation in the BOD. The experimental design used was completely randomized in a $16 \times 2$ bifactorial scheme (cultivars $\mathrm{x}$ pollen storage conditions), with four replicates of one blade each.

The average pollen production and viability data were subjected to the Lilliefors normality test, transformed by $\sqrt{Y_{i j}+1 / 2}$ for pollen production and by $\log 10^{\left(Y_{i j}+1\right)}$ for pollen viability, as well as the variance analysis and subsequent grouping of means by the Scott-Knott test at $\alpha=0.05$, with the aid of the Genes statistical software (CRUZ, 2016).

\section{Results and discussion}

An interaction was observed between the factors tested for the average number of pollen grains per anther. Most cultivars showed higher pollen per anther production in 2016 compared to 2017. The cultivars Bonão, Charme, Douradão, Eldorado, Granada, and Marli, despite not having high pollen production, did not differ statistically between years (Table 1), suggesting that they are less affected by climatic variations between years. In 2016, the cultivars BR-1, Kampai, Regalo, Riograndense, Rubimel, and Zilli showed the highest pollen production per anther, proving to be more demanding and responsive to the supply of cold in the winter. In the crop year 2017, the cultivars which produced the least pollen were Coral and Chimarrita, while the others were more productive; however, the difference was not significant (Table 1).

Barbosa et al. (1989) suggested that in the cultivars most adapted to the subtropical climate, the production of pollen per anther can vary between 1,000 and 2,000 grains, possibly originating up to 80,000 grains of pollen per flower.

Pollen per anther production in crop year 2016 ranged from 280 to 1,220 grains, where the cultivars Regalo, and Riograndense had a production greater than 1,000 pollen grains per anther (Table 1). Based on information from Barbosa (1989), only these last two cultivars and, possibly, also the cultivars BR-1, Kampai, Rubimel, and Zilli would have good climatic adaptation in Dois Vizinhos, Paraná State, Brazil. In that year, peaches experienced 185 cold hours $(\mathrm{CH}) \leq 7.2{ }^{\circ} \mathrm{C}$ (INMET, 2018). In the crop year 2017, the pollen grains production per anther varied from 25 to 525 (Table 1), demonstrating for this variable that the winter conditions of 2017, from May to August (107 $\mathrm{CH} \leq 7.2{ }^{\circ} \mathrm{C}$ ) (INMET, 2018), were less favorable to the development of floral structures, including pollen, as well as to overcome bud dormancy. 
Table 1. Number of pollen grains per anther of 16 peach cultivars, 2016 and 2017 years. UTFPR-DV, Paraná State, Brazil, 2020.

\begin{tabular}{lccc}
\hline \multirow{2}{*}{ Cultivars } & \multicolumn{2}{c}{ Number of pollen grains per anther } & \multirow{2}{*}{ Means } \\
\cline { 2 - 3 } & $\mathbf{2 0 1 6}$ * $^{*}$ & $505 \mathrm{aA}$ & $\mathbf{4 8 0}$ \\
Bonão & $455 \mathrm{bA}$ & $300 \mathrm{aB}$ & $\mathbf{6 2 0}$ \\
BR-1 & $940 \mathrm{aA}$ & $385 \mathrm{aA}$ & $\mathbf{3 7 0}$ \\
Charme & $355 \mathrm{bA}$ & $50 \mathrm{bB}$ & $\mathbf{3 5 2}$ \\
Chimarrita & $655 \mathrm{bA}$ & $25 \mathrm{bB}$ & $\mathbf{2 5 7}$ \\
Coral & $490 \mathrm{bA}$ & $350 \mathrm{aA}$ & $\mathbf{3 1 5}$ \\
Douradão & $280 \mathrm{bA}$ & $190 \mathrm{aA}$ & $\mathbf{3 1 2}$ \\
Eldorado & $435 \mathrm{bA}$ & $170 \mathrm{aB}$ & $\mathbf{3 5 5}$ \\
Fascínio & $540 \mathrm{bA}$ & $305 \mathrm{aA}$ & $\mathbf{3 9 7}$ \\
Granada & $490 \mathrm{bA}$ & $330 \mathrm{aB}$ & $\mathbf{6 2 0}$ \\
Kampai & $910 \mathrm{aA}$ & $205 \mathrm{aB}$ & $\mathbf{3 6 2}$ \\
Leonense & $520 \mathrm{bA}$ & $525 \mathrm{aA}$ & $\mathbf{4 7 2}$ \\
Marli & $420 \mathrm{bA}$ & $435 \mathrm{aB}$ & $\mathbf{8 2 7}$ \\
Regalo & $1220 \mathrm{aA}$ & $265 \mathrm{aB}$ & $\mathbf{7 3 7}$ \\
Riograndense & $1210 \mathrm{aA}$ & $295 \mathrm{aB}$ & $\mathbf{5 8 7}$ \\
Rubimel & $880 \mathrm{aA}$ & $390 \mathrm{aB}$ & $\mathbf{6 7 7}$ \\
Zilli & $965 \mathrm{aA}$ & $\mathbf{2 9 5}$ & $\mathbf{4 8 4}$ \\
\hline Means & $\mathbf{6 7 3}$ & & \\
\hline CV (\%) & & $\mathbf{3 4 , 2}$ & \\
\hline
\end{tabular}

*Averages followed by the same lowercase letter in the column and the same uppercase letter in the row do not differ statistically from each other by the Scott$\operatorname{Knott}(\alpha=0.05) ; \mathrm{CV}=$ variation coefficient.

In the evaluations for pollen germination stored for 60 days at $-20{ }^{\circ} \mathrm{C}$ (Table 2), comparing years, with the exception of the cultivars Charme, Douradão, and Riograndense, which were higher in 2017 and, the cultivar Kampai, which was higher in 2016, all other cultivars showed similar germination rates in the two years of evaluation, without statistical differences. These results demonstrate that in vitro pollen germination depends more strictly on the air temperature at this phenological stage (flowering), than on the cold supply to overcome the dormancy of the buds.

The cultivar with the highest germination rate in 2016 was Leonense, (30.5\%). In 2017, the cultivars that showed the most viable pollen were the cultivars Douradão (30.4\%), Leonense (25.7\%), Regalo (28.6\%), and Rubimel (23.2\%) (Table 2). However, these results are much lower than those obtained by Barbosa (1991), who, when testing the conservation of peach pollen stored in a freezer desiccator $\left(0 \pm 1^{\circ} \mathrm{C}\right)$ over a period of 60 days, obtained germination rates $>70 \%$.

Similar results to Barbosa (1991) were described by Oliveira, Maués and Kalume (2001) for the viability test of Açaí (Euterpe oleracea) pollen stored in a freezer (-10 ${ }^{\circ} \mathrm{C}$ ) during the periods of $1,3,6$, and 12 months. Oliveira, Maués and Kalume (2001) also found that despite a reduction in the pollen germination rate with conservation time, for one month of storage the average index was $79.6 \%$, and for the other months the rates were $77.4 \%$,
$74.1 \%$, and $61.3 \%$, respectively. The low germination rates, for both years, could be associated with the same factors that generated the low levels of pollen production per anther (Table 1).

For pollen germination indexes at 7 days (drying at ambient temperature) and pollens stored for 60 days $\left(-20^{\circ} \mathrm{C}\right)$, it was found that the best results were at 7 days for most cultivars. The cultivars Bonão, Charme, and Kampai showed no statistical difference between the two conservation times, despite the low germination rates, especially in the last two cultivars (Table 3 ).

For Charme cultivar, the data seem to indicate pollen conservation stability under extreme temperature conditions. At seven days, the cultivars with the highest percentages were BR-1 (36.6\%), Douradão (39.1\%), Leonense (41.0\%), Marli (35.9\%), and Regalo (43.4\%). At 60 days, the cultivars were superior. Storage for 60 days at $-20^{\circ} \mathrm{C}$ reduced pollen viability by $42 \%$ (Table 3 ). 
Table 2. Percentage of pollen grains germinated after seven days of drying at room temperature plus 60 days in silica desiccator at $-20^{\circ} \mathrm{C}$ of 16 peach cultivars, in the 2016 and 2017 years. UTFPR-DV, Paraná State, Brazil, 2020.

\begin{tabular}{lccc}
\hline \multirow{2}{*}{ Cultivars } & \multicolumn{2}{c}{ Pollen germination $\mathbf{( \% )}$} & \multirow{2}{*}{ Means } \\
\cline { 2 - 3 } & $\mathbf{2 0 1 6}$ & $\mathbf{2 0 1 7}$ & $\mathbf{3 , 6}$ \\
Bonão & $6,5 \mathrm{cA}$ & $0,7 \mathrm{cA}$ & $\mathbf{1 1 , 6}$ \\
BR-1 & $8,8 \mathrm{cA}$ & $14,4 \mathrm{bA}$ & $\mathbf{1 4 , 9}$ \\
Charme & $7,7 \mathrm{cB}$ & $22,0 \mathrm{bA}$ & $\mathbf{2 1 , 1}$ \\
Chimarrita & $23,9 \mathrm{bA}$ & $18,3 \mathrm{bA}$ & $\mathbf{3 , 2}$ \\
Coral & $2,1 \mathrm{cA}$ & $4,2 \mathrm{cA}$ & $\mathbf{2 4 , 5}$ \\
Douradão & $18,6 \mathrm{bB}$ & $30,4 \mathrm{aA}$ & $\mathbf{4 , 4}$ \\
Eldorado & $5,4 \mathrm{cA}$ & $3,4 \mathrm{cA}$ & $\mathbf{8 , 4}$ \\
Fascínio & $5,1 \mathrm{cA}$ & $11,6 \mathrm{cA}$ & $\mathbf{1 1 , 8}$ \\
Granada & $7,4 \mathrm{cA}$ & $16,2 \mathrm{bA}$ & $\mathbf{1 1 , 3}$ \\
Kampai & $20,1 \mathrm{bA}$ & $2,6 \mathrm{cB}$ & $\mathbf{2 8 , 1}$ \\
Leonense & $30,5 \mathrm{aA}$ & $25,7 \mathrm{aA}$ & $\mathbf{1 2 , 7}$ \\
Marli & $15,3 \mathrm{bA}$ & $10,1 \mathrm{cA}$ & $\mathbf{2 4 , 6}$ \\
Regalo & $20,6 \mathrm{bA}$ & $28,6 \mathrm{aA}$ & $\mathbf{1 5 , 2}$ \\
Riograndense & $9,8 \mathrm{cB}$ & $20,6 \mathrm{bA}$ & $\mathbf{2 2 , 5}$ \\
Rubimel & $21,8 \mathrm{bA}$ & $23,2 \mathrm{aA}$ & $\mathbf{7 , 3}$ \\
Zilli & $9,8 \mathrm{cA}$ & $4,7 \mathrm{cA}$ & $\mathbf{1 4 , 1}$ \\
\hline Means & $\mathbf{1 3 , 3}$ & $\mathbf{1 4 , 8}$ & \\
\hline CV $(\%)$ & & $\mathbf{1 8 , 0}$ & \\
\hline
\end{tabular}

* Averages followed by the same lowercase letter in the column and the same uppercase letter in the row do not differ statistically from each other by the Scott-Knott $(\alpha=0.05) ; \mathrm{CV}=$ variation coefficient.

Table 3. Pollen germination rates at 07 days (room temperature) and 60 days $\left(-20^{\circ} \mathrm{C}\right)$ of 16 peach cultivars in 2017 year. UTFPR-DV, Paraná State, Brazil, 2020.

\begin{tabular}{lccc}
\hline \multirow{2}{*}{ Cultivars } & \multicolumn{2}{c}{ Pollen germination (\%) } & \multirow{2}{*}{ Means } \\
\cline { 2 - 3 } Bonão & $\mathbf{0 7}$ dias & $\mathbf{6 0}$ dias & \\
BR-1 & $1,0 \mathrm{dA}$ & $0,7 \mathrm{dA}$ & $\mathbf{0 , 9}$ \\
Charme & $36,6 \mathrm{aA}$ & $14,4 \mathrm{bB}$ & $\mathbf{2 5 , 5}$ \\
Chimarrita & $24,1 \mathrm{bA}$ & $22,0 \mathrm{bA}$ & $\mathbf{2 3 , 1}$ \\
Coral & $33,4 \mathrm{bA}$ & $18,3 \mathrm{bB}$ & $\mathbf{2 5 , 8}$ \\
Douradão & $15,2 \mathrm{cA}$ & $4,2 \mathrm{~dB}$ & $\mathbf{9 , 7}$ \\
Eldorado & $39,1 \mathrm{aA}$ & $30,4 \mathrm{aB}$ & $\mathbf{3 4 , 8}$ \\
Fascínio & $32,6 \mathrm{bA}$ & $3,4 \mathrm{~dB}$ & $\mathbf{1 8 , 0}$ \\
Granada & $20,2 \mathrm{cA}$ & $11,6 \mathrm{cB}$ & $\mathbf{1 5 , 9}$ \\
Kampai & $31,6 \mathrm{bA}$ & $16,2 \mathrm{bB}$ & $\mathbf{2 3 , 9}$ \\
Leonense & $3,2 \mathrm{dA}$ & $2,6 \mathrm{dA}$ & $\mathbf{2 , 9}$ \\
Marli & $41,0 \mathrm{aA}$ & $25,7 \mathrm{aB}$ & $\mathbf{3 3 , 3}$ \\
Regalo & $35,9 \mathrm{aA}$ & $10,1 \mathrm{cB}$ & $\mathbf{2 3 , 0}$ \\
Riograndense & $43,4 \mathrm{aA}$ & $28,6 \mathrm{aB}$ & $\mathbf{3 6 , 0}$ \\
Rubimel & $29,6 \mathrm{bA}$ & $20,6 \mathrm{bB}$ & $\mathbf{2 5 , 1}$ \\
Zilli & $34,2 \mathrm{bA}$ & $23,2 \mathrm{aB}$ & $\mathbf{2 8 , 7}$ \\
Means & $19,9 \mathrm{cA}$ & $4,7 \mathrm{~dB}$ & $\mathbf{1 2 , 3}$ \\
\hline CV (\%) & $\mathbf{2 5 , 6}$ & $\mathbf{1 4 , 8}$ & $\mathbf{2 1 , 2}$ \\
\hline
\end{tabular}

\footnotetext{
* Averages followed by the same lowercase letter in the column and the same uppercase letter in the row do not differ statistically from each other by the Scott-Knott $(\alpha=0.05) ; \mathrm{CV}=$ variation coefficient.
} 
Although the results obtained in the present study are below an ideal $70 \%$ germination rate (BARBOSA, 1991), the pollen germination rates at seven days were acceptable (mean of $25 \%$ ) which, possibly, would be sufficient to obtain good rate of effective fruiting (NAVA, 2007). Scorza and Sherman (1995) found that suitable pollen must show $50-80 \%$ germination with welldeveloped tubes. Scorza and Sherman (1995) also found, however, that the presence of some vigorous pollen tubes may still ensure moderate effective fruiting, despite the low rate of germination.

Reis et al. (2009), when carrying out germination tests of pollen grains and pollen tube length of 17 peach cultivars, report that for the initial evaluation of germination without pollen storage in freezer, most cultivars showed satisfactory germination levels (50$80 \%$ ). For grains stored for 90 days at a temperature of $-16.5^{\circ} \mathrm{C}$, they maintained their germination viability at $60 \%$.
In germination tests of guabirobeira (Campomanesia xanthocarpa berg) pollen stored for 90 days $\left(-18^{\circ} \mathrm{C}\right)$ lost viability, with a reduced rate of 43.8 to $1.0 \%$ (FRANZON; RASEIRA; WAGNER JÚNIOR, 2006).

Franzon and Raseira (2006) found, in contrast, that pollen grains of cherry (Eugenia involucrata) stored for 90 days at a temperature of $-16.5^{\circ} \mathrm{C}$ maintained their germination viability at $60 \%$. This demonstrates that cold pollen conservation is highly variable among species.

For pollen to maintain its viability at satisfactory levels for agricultural production, dissociated from the storage time, it is necessary to consider the factors of temperature, relative humidity of the environment, and also the degree of humidity of the pollen grain at the time of storage (GOMES et al., 2000).

For pollen germination, when comparing incubation times in BOD, it was found that the means for germination rates of 4 and 20 hours did not differ significantly, with an average rate of $14.5 \%$ (Table 4 ). Four-hour of incubation at $25{ }^{\circ} \mathrm{C}$ under photoperiod is therefore sufficient for pollen germination to occur.

Table 4. Pollen germination rates, with different incubation times at $25^{\circ} \mathrm{C}$, of 16 peach cultivars in 2016 year. UTFPRDV, Paraná State, Brazil, 2020.

\begin{tabular}{|c|c|c|c|}
\hline \multirow{2}{*}{ Cultivars } & \multicolumn{2}{|c|}{ Pollen germination $(\%)$} & \multirow{2}{*}{ Means } \\
\hline & 04 horas & 20 horas & \\
\hline Bonão & 6,5 & 7,4 & $7.0 \mathrm{~b}$ \\
\hline BR-1 & 8,8 & 9,5 & $9,2 \mathrm{~b}$ \\
\hline Charme & 7,7 & 7,6 & $7,6 \mathrm{~b}$ \\
\hline Chimarrita & 23,9 & 28,6 & 26,3 a \\
\hline Coral & 2,1 & 4,0 & $3,1 \mathrm{~b}$ \\
\hline Douradão & 18,6 & 31,0 & 24,8 a \\
\hline Eldorado & 5,4 & 6,3 & $5,8 \mathrm{~b}$ \\
\hline Fascínio & 5,1 & 5,4 & $5,2 \mathrm{~b}$ \\
\hline Granada & 7,4 & 10,2 & $8,8 \mathrm{~b}$ \\
\hline Kampai & 20,1 & 19,9 & 20,0 a \\
\hline Leonense & 30,5 & 29,5 & 30,0 a \\
\hline Marli & 15,3 & 15,8 & $15,5 \mathrm{~b}$ \\
\hline Regalo & 20,6 & 24,0 & 22,3 a \\
\hline Riograndense & 9,8 & 11,1 & $10,5 \mathrm{~b}$ \\
\hline Rubimel & 21,8 & 25,7 & 23,7 a \\
\hline Zilli & 9,8 & 13,0 & $11,4 \mathrm{~b}$ \\
\hline Means & $13,3 \mathrm{~A}$ & $15,6 \mathrm{~A}$ & 14,5 \\
\hline CV (\%) & & 20,4 & \\
\hline
\end{tabular}

*Averages followed by the same lowercase letter in the column and the same uppercase letter in the row do not differ statistically from each other by the Scott$\operatorname{Knott}(\alpha=0.05) ; \mathrm{CV}=$ variation coefficient. 
Chimarrita, Douradão, Kampai, Leonense, Regalo, and Rubimel were the cultivars that presented the best germination rates (above $20 \%$ ) (Table 4). However, according to Nava (2007), none of the cultivars exceeded $70 \%$ germination, which would be expected in wellmanaged orchards of cultivars adapted to the climate.

\section{Conclusions}

Winter conditions in 2016 were better for bud development, promoting greater production of pollen per anther.

The cultivars Douradão, Leonense, Regalo, and Rubimel had higher pollen viability.

The storage of peach pollen for 60 days at $-20{ }^{\circ} \mathrm{C}$ reduces its viability by $42 \%$.

Four-hour incubation time, with photoperiod, is sufficient to promote the germination of peach pollen.

\section{Acknowledgment}

The authors thank the Federal Technological University of Paraná, Câmpus Dois Vizinhos, and the Postgraduate Program in Agroecosystems for providing the physical structure, and human and economic resources to carry out the work.

\section{References}

ALMEIDA, G.K.; MAGRIN, F.P.; SOLDATELLI, P.; FIORAVANÇO, J.C. Fenologia e produtividade de cultivares de pessegueiros Revista de Ciências Agroveterinárias, Lages, v.13, n.3, p.11, 2014.

ALVARES, C.A.; STAPE, J.L.; SENTELHAS, P.C.; GONÇALVES, J.L. de M.; SPAROVEK, G. Köppen's climate classification map for Brazil. Meteorologische Zeitschrift, Sttugart, v.22, n.6, p.711-728, 2013.

BARBOSA, W.; CAMPO-DALLÓRTO, F.A.; OJIMA, $M$. Comportamento vegetativo e reprodutivodo pessegueiro IAC Tropical. Campinas: IAC, 1989. (Boletim Científico)

BARBOSA, W.; DALL'ORTO, F.A.C.; OJIMA, M.; MARTINS, F.P.; BOAVENTURA, Y.M.S. Conservação e germinação do pólen, polinização e frutificação efetiva em pessegueiros e nectarineiras subtropicais. Bragantia, Campinas, v.50, n.1, p.17-28, 1991.

CARVALHO, T.C.P. Comportamento de algumas cultivares de Ameixeira Japonesa (Prunus salicina) quanto à polinizacão no Rio Grande do Sul. 1989. Dissertacão (Mestrado em Agronomia) - Universidade Federal de Pelotas, Pelotas, 1989.
CARAMORI, P.H.; CAVIGLIONE, J.H.; WREGE, M.S.; HERTER, F.G.; HAUAGGE, R.; VES, S.L.G.; CITADIN, I.; RICCE, W. da S. Zoneamento agroclimático para o pessegueiro e a nectarineira no estado do Paraná. Revista Brasileira de Fruticultura, Jaboticabal, v.30, n.4, p.10401044, 2008.

CHAGAS, E.A.; BARBOSA, W.; PIO, R.; DALL'ORTO, F.A.C.; TIZATO, L.H.G.; SAITO, A.; CHAGAS, P.C.; FILHO, J.A.S. Germinação in vitro de grãos de pólen de Prunus pérsica (L.) Batsch vulgaris. Bioscience Journal, Uberlândia, v.25, n.5, p.8-14, 2009.

CRUZ, C.D. Programa genes: estatística experimental e matrizes. Viçosa: Universidade Federal de Viçosa, 2016. $285 p$.

EINHARDT, P.M.; CORREA, E.R.; RASEIRA, M.C.B. Comparação entre métodos para testar a viabilidade de pólen de pessegueiro. Revista Brasileira de Fruticultura, Jaboticabal, v.28, n.1, p.5-7, 2006.

FRANZON, R.C.; RASEIRA, M.C.B. Germinação in vitro e armazenamento do pólen de Eugenia involucrata DC Myrtaceae. Revista Brasileira de Fruticultura, Jaboticabal, v.28, n.1, p.18-20, 2006.

FRANZON, R.C.; RASEIRA, M.C.B.; WAGNER JÚNIOR, A. Germinação in vitro de pólen de guabirobeira (Campomanesia xanthocarpa Berg). Revista Ceres, Viçosa, MG, v.53, n.305, p.129-134, 2006.

FRANZON, R.C.; RASEIRA, M.C.B.; WAGNER JÚNIOR, A.T este de germinação in vitro e armazenamento de pólen de pitangueira (Eugenia uniflora L.) Revista Acta Scientiarum Agronomy, Maringá, v.29, n.2, p.251-255, 2007.

GOMES, P.R.; RASEIRA, M.C.B.; GARCIA, A.SILVA, J.B. Germinação in vitro do pólen de cebola (Allium cepa L.). Agropecuária Clima Temperado, Pelotas, v.3, n.2, p193-198, 2000.

IBGE - Instituto Brasileiro de Geografia e Estatística. Produção agrícola. Rio de Janeiro, 2020. Disponível em: http://www.sidra.ibge.gov.br/bda/tabela/listabl1.as $\mathrm{p} ? \mathrm{c}=1613 \& \mathrm{n}=0 \& \mathrm{u}=0 \& \mathrm{z}=\mathrm{t} \& \mathrm{o}=1 \& \mathrm{i}=\mathrm{P}$. Acesso em: 18 fev. 2020 .

INMET - Instituto Nacional de Meteorologia . Consulta de dados da estação automática: Dois Vizinhos (PR). Disponível em: http://www.inmet.gov.br/sonabra/ pg_dspDadosCodigo_sim.php?QTg0Mw. Acesso em: 14 jan. 2018. 
NAVA, G.A. Desenvolvimento floral e frutificação de pessegueiros (Prunus persica L. Bastch) cv. Granada, submetidos a distintas condições térmicas durante o período de pré-floração e floração. Tese (Doutorado em Fitotecnia) - Universidade Federal do Rio Grande do Sul, Porto Alegre, 2007.

NAVA, G.A.; DALMAGO, G.A.; BERGAMASCHI, H.; PANIZ, R.; DOS SANTOS, R.P.; MARODIN, G.A.B. Effect of high temperatures in the pre-blooming and blooming periods on ovule formation, pollen grains and yield of 'Granada' peach. Scientia Horticulturae, Wageningen, v.122, p.37-44, 2009.

OLIVEIRA, M.S.P.; MAUÉS, M.M; KALUME, M.A.A. Viabilidade de pólen in vivo em genótipo de açaizeiro. Acta Botanica Brasilica, São Paulo, v.15, n.1, p.27-33, 2001.
PETRI, J.L.; LEITE, G.B.; YASUNOBU, Y. Studies on the causes of floral bud abortion of japanase pear (Pyrus pyrifolia) in Southern Brazil. Acta Horticulturae, The Hague, n.587, p.375-780, 2002.

REIS, L.; CITADIN, I.; PENSO, G. A.; MALAGI, G.; SACHET, M. R. Teste de viabilidade de pólen como ferramenta em programa de melhoramento de pessegueiro. In: XIV SICITE - Seminário de Iniciação Científica e Tecnológica. 1. 2009. Pato Branco. Anais. Pato Branco: UTFPR, 2009.

SCORZA, R.; SHERMAN, W.B. Peaches. In: JANIK J.; MOORE, J.N. (Ed.). Fruit breeding. New York: John \& Sons, 1995. p.325-440.

WAGNER JÚNIOR, A; BRUCKNER, C.H.; SILVA, J.O.da C.; SANTOS, C.E.M. dos.; PIMENTEL, L.D.; MAZARO, S.M. Adaptação de genótipos de pessegueiros F2 para condições de baixo acúmulo de frio hibernal. Bragantia, Campinas, v.69, n.4, p.815-822, 2010. 